\title{
PERJALANAN MENUJU KEBERMAKNAAN HIDUP BERSAMA PANDEMI
}

\section{Helma Nuraini}

FTK UIN Antasari; Jl. Ahmad Yani km. 4,5 Banjarmasin

Email: helmanuraini2@gmail.com

\section{PANDEMI DAN MINDLESSNESS}

Sejak pelaporan kasus Covid-19 oleh Negara China pada awal Desember 2019 kepada WHO, belum ada ramalan yang cukup kuat mengenai kapan wabah ini akan berakhir (Arnani, 2020). Hal ini dikarenakan globalisasi dan tingkat konektivitas masyarakat yang tinggi menjadikan virus ini akan terus ada walaupun virusnya sudah ditemukan (Anwar, 2020).

Dalam perkembangannya, bukan hanya pandemi yang terjadi, namun muncul pula infodemi; meluapnya informasi mengenai Covid-19 yang didominasi oleh berita palsu. Saat Covid-19 mulai diberitakan media massa, mengalirlah berbagai broadcast di media sosial dan aplikasi percakapan yang didominasi berita hoax dan kesimpangsiuran informasi yang meresahkan masyarakat, sebagai contoh, beredarnya video mengenai kasus "korban corona" yang mati mendadak setelah mengalami kejang-kejang di suatu bandara (Sawitri, 2020). Informasi sesat mengenai penyebab munculnya Virus Corona (Rahman, 2020), iklan bombastis obat Virus Corona (Himawan, 2020), berita-berita yang menyudutkan etnis China, pemerintah, dokter dan rumah sakit, hingga berbagai teori konspirasi "membanjiri otak", sehingga mampu mengurangi kewarasan berpikir.

Dalam hal ini, infodemi akan menghambat kemampuan individu dan masyarakat dalam mengambil langkah efektif dalam menghadapi pandemi, bukan hanya terkait dengan Virus Covid-19 
namun juga efek-efek psikologis yang menyertai seperti kecemasan berlebih, panic buying bahan kebutuhan pokok dan sarana kesehatan, meyakini stigma dan klaim tidak rasional mengenai pandemi atau sebaliknya, menjadi tidak peduli dan bahkan tidak memercayai hal-hal terkait Covid-19 seperti yang saat ini terjadi pada sebagian masyarakat pada kalangan tertentu (Purnamasari, 2020, Saputra, 2020, Prasetiyo, 2020). Pengabaian protokol kesehatan yang dilakukan sebagian orang menjadikan situasi menjadi lebih berkonflik, terasa serba tidak pasti, dan terasa lebih mencemaskan.

Pandemi Covid-19 telah memberi dampak perubahan menyeluruh dalam tatanan kehidupan manusia. Dua hal yang paling mendasar yakni tatanan hidup baru yang diskenariokan sebagai era normal baru dan juga basic needs menjadi persoalan yang mengemuka di sepanjang tahun 2020 ini. Pandemi ini dengan serta merta menuntut setiap individu - tanpa memandang kelas sosial- untuk beradaptasi dengan cepat demi mencapai keseimbangan hidup sekaligus kesehatan fisik dan mentalnya.

Siapa yang tidak cemas jika wilayah tempat tinggalnya ditetapkan sebagai zona hitam Covid-19? Apakah kehidupan bisa tetap berjalan dengan tenang ketika masyarakat tidak memedulikan protokol kesehatan, atau kerumunan terjadi di tempat umum? Belum lagi jika dampak pandemi ini berimbas pada permasalahan ekonomi, kekerasan dalam rumah tangga (KDRT) dan persoalan sosial lainnya seperti peningkatan kriminalitas atau perilaku maladaptif yang dilakukan oleh remaja.

Dampak situasi pandemi menampakkan dengan tepat kondisi ketidakmampuan sebagian besar orang dalam mengatasi dan menghadapinya guncangan pandemi. Suatu kondisi mindlessness; masyarakat yang tidak mampu dengan tepat mengambil sikap dikarenakan kemasabodohan, ketidaktahuan dan ketidakrasionalan dalam bertindak. Mindlessness dalam kamus Cambrigde 
didefinisikan sebagai the quality of being stuoid and meaning nothing atau the quality of not needing much thought or mental effort(https://dictionary.cambridge.org/dictionary/english/mindless ness).

Masyarakat masih belum mampu mengambil jarak dari tradisi "kumpul-kumpul". Arisan, pengantinan dan acara "makan-makan" masih dan makin marak dilakukan oleh masyarakat. Perilaku bersalaman masih sulit untuk ditinggalkan, pesan untuk menjaga jarak masih sering terlupakan dan penggunaan masker dengan asalasalan, merupakan contoh dari mindlessness/kecerobohan yang kemudian menciptakan klaster-klaster baru penyebaran Covid-19 di kalangan keluarga dan komunitas sosial.

Mindlessness mengacu pada ketidakpedulian, terjebak pada masa lalu, terperangkap dalam perspektif yang kaku serta ketidakpekaan terhadap fenomena yang dialaminya (Iresearchnet.com, tanpa tahun). Kemampuan adaptasi terhadap perubahan budaya dan sikap mental masih belum dapat teratasi dan bahkan menimbulkan permasalahan baru dan penurunan kualitas kehidupan. Budaya baru yang seharusnya terbentuk dengan adanya pandemi ini masih belum banyak berubah.

\section{PANDEMI DAN MINDFULNESS}

Penetapan new normal atau tatanan baru dalam rangka memastikan agar masyarakat dapat beraktivitas kembali dengan aman di tengah wabah covid-19 dalam kenyataannya tidak sepenuhnya dapat diadaptasi dengan baik. New Normal justru menimbulkan euphoria, semacam kebebasan dari keterkekangan, kebebasan dari kebosanan "dikurung di rumah" yang semuanya patut dirayakan kembali dengan bersenang-senang bersama keluarga dan komunitas.

Euphoria ini mesti dibayar mahal dengan masih terus 
bertambahnya kasus positif orang-orang yang terpapar Covid-19. Pengabaian dan ketidakpatuhan menjalankan protokol kesehatan terjadi hampir di setiap kota. Hal ini tidak saja dilakukan masyarakat awam, namun juga para tokoh dan orang-orang dari kalangan menengah ke atas bahkan sebagian dari pejabat pemerintah.

Saat ini, rumah sakit masih penuh dengan pasien yang terpapar Covid-19. Berita-berita publik figur yang mengalami hal sama pun hampir tiap hari ditemui di media massa. Sekolahsekolah yang berada di zona hijau dan mendapat izin menyelenggarakan kegiatan pembelajaran, sebagian diantaranya harus memberlakukan kembali pembelajaran jarak jauh. Sempat pula ramai pemberitaan di berbagai media massa dan media daring keluhan dan protes para orang tua yang menginginkan persekolahan dimulai. Hal ini dikarenakan para orang tua mulai dan telah tidak sanggup memberikan pembelajaran di rumah dan sistem daring yang diterapkan dianggap tidak efektif dan menimbulkan berbagai masalah baru. Para remaja, anak-anak dan orang dewasa mendapatkan kesempatan luas untuk melakukan aktivitas yang disukainya, misalnya dengan semakin maraknya dan viralnya beberapa game online.

Berbagai persoalan sertaan yang mengemuka merupakan bentuk dari ketidakmampuan masyarakat untuk beradaptasi dengan cepat terhadap perubahan di masa pandemi. Masyarakat masih sulit untuk mengubah budaya yang terbentuknya juga tidak melalui proses kesadaran. Kehidupan dan kebudayaan berjalan hanya sebagai bentuk ketertundukan pada budaya mapan. Budaya yang terbangun selama ini hanya "mengalir" serta hanya mengedepankan respon terhadap faktor-faktor yang berasal dari luar, tanpa memertimbangkan faktor dari dalam diri manusia sendiri.

Mindfulness merupakan konsep kesadaran diri pribadi dalam 
rangka mendapatkan wawasan baru dalam keseharian hidup. Dengan pelibatan mindfulness, segala sesuatu yang dirasakan normal atau biasa saja dapat berubah menjadi lebih bermakna mendalam dan karenanya mampu menghasilkan insight yang mampu memerkaya jiwa. Mindfulness bermakna pengosongan pikiran dari kecemasan, merasakan lebih dalam ke dalam diri dan mulai berfokus pada kesadaran diri yang reflektif dan lebih bermakna (Dundon, 2019).

Covid-19 menyadarkan bahwa kehidupan harus dimaknai kembali melalui proses penyadaran situasi here and now demi harapan dan target masa depan yang tidak fana. Kematian, penderitaan adalah bagian dari kehidupan yang mengajak pergi pada keabadian. Apa yang dapat dilakukan untuk mencapai kesadaran penuh ini yaitu kembali pada sumber keabadian, yaitu Tuhan. Bagi umat beragama, penguatan pada akidah dan ibadah serta amal menjadi jalan kembali.

Kesadaran diri merupakan proses mengenal diri dengan tiga jalinan relasi eksistensial, yaitu hubungan diri dengan orang lain, dengan Tuhan dan lingkungan. Salah satu bentuk upaya untuk menuju pada kesadaran sebagai manusia yakni dengan menjalankan 5 hal yang dikenal sebagai Obat Hati. Syair dan lagu Obat Hati yang menurut sejarah diciptakan oleh Sunan Bonang (Huda, 2015), merupakan suatu bentuk dari kondisi mindfulness, yaitu kesadaran untuk menemukan makna hidup yang hakiki. Berikut syair Tombo Ati dalam terjemahan Bahasa Indonesia:

Obat hati ada lima perkaranya

Yang pertama baca Qur'an dan maknanya

Yang kedua sholat malam dirikanlah

Yang ketiga berkumpullah dengan orang soleh

Yang keempat perbanyaklah berpuasa

Yang kelima dzikir malam perpanjanglah 
Salah satunya siapa bisa menjalani

Moga-moga Allah Ta'ala mencukupi

Sudah tidak diragukan bahwa membaca Qur'an akan menimbulkan ketenangan batin. Membaca Qur'an dan menghayati maknanya akan menimbulkan kesadaran dan pemahaman diri, terbukanya wawasan untuk mengikuti petunjuk sebagai dasar bagi kesalehan pribadi dan kesalehan sosial. Sholat malam merupakan ritual yang lebih subtil untuk berada pada situasi transenden. Sholat malam menjadikan seorang individu mampu mengambil jarak dari permasalahan hidup, lebih sadar, lebih damai, semakin berserah dan cukup Allah SWT saja tempat untuk bersandar dan memohon pertolongan.

Lagu Obat Hati juga menyarankan untuk menemukan orang soleh sebagai sarana menemukan kesadaran diri. Kesadaran diri bersama dapat ditempuh melalui kegiatan dan tindakan kolektif dari orang-orang yang memiliki kesalehan. Saran menjalankan ibadah puasa juga merupakan cara untuk menahan laju pikiran dan emosi demi menemukan esensi dari eksistensi diri. Berpuasa juga berdampak pada munculnya rasa empati karena individu sedang "menyucikan dirinya" dari hawa nafsu keduniawian.

Esensi mindfulness dalam Islam berada dalam ritual dzikir. Dzikir merupakan sarana merenung, berkontemplasi sekaligus jalan bagi pertemuan dengan Allah SWT. Saat dzikir dilantunkan, saat kalimat-kalimat thayyibah terucap secara spontan, maka saat itulah mindfulness menemukan momennya.

Dalam Islam, posisi manusia bukan sebagai penguasa, namun pengemban amanah. Alam merupakan amanah yang lebih diarahkan pada kemanfaatan ke dalam yang lebih memberi makna kesadaran/mindfulness demi penghambaan pada Allah SWT. Hal ini juga menyambung dengan bentuk relasi dengan sesama yang mengedepankan relasi sesama, yaitu membangun empati dan 
solidaritas.

Dalam konteks pandemi, mengamalkan salah satu saja dari lima Obat Hati merupakan bentuk dari tanggung jawab pribadi dalam rangka menjaga kewarasan mental dan kesehatan fisik. Kesadaran diri ini sekaligus akan meluas pada suatu kesadaran kemanusiaan. Kesadaran yang menempatkan individu berada bersama secara kolektif dengan individu-individu lain. Segala tindakan yang dilakukan individu atau peran yang dijalankannya berdampak pada orang lain. Dengan demikian, tanggung jawab pada diri sendiri sadar pada tanggung jawab kepada orang lain.

Dalam praktiknya bentuk kesadaran dan tanggung jawab individu di masa pandemi ini dapat dilakukan melalui kepatuhan untuk menjalankan skenario new normal yang ditetapkan pemerintah. Kepatuhan ini haruslah berasal dari kesadaran dan amanah bahwa sekecil apapun langkah positif pencegahan penularan Virus Covid-19 haruslah dilaksanakan secara sungguhsungguh dan konsisten. Berikutnya, individu dan masyarakat perlu menghargai upaya berbagai pihak yang mengusahakan agar pandemi segera berlalu. Dalam hal ini sikap egois dan diskriminasi terhadap korban Covid haruslah dijauhkan, empati dan kepedulian nyata perlu diwujudkan misalnya melalui pemberian donasi bagi pihak-pihak yang terdampak Covid.

\section{PANDEMI DAN MEANINGFULNESS}

Blessing in disguise, selalu ada hikmah dalam setiap bencana, Covid-19 terjadi karena kehendak Allah SWT, dan tentunya banyak hikmah yang dapat diraih bagi orang-orang yang bersedia mencari, memahami dan menerimanya. Dalam hal ini tentu saja makna yang didapatkan setiap orang tidaklah akan sama. Setiap orang akan memaknainya sesuai kapasitas pemahaman serta kepedulian yang dimilikinya.

Tatanan kehidupan yang berubah dengan cepat dan masif di 
masa pandemi ini tentu saja mengandung pelajaran yang teramat berharga bagi seluruh penghuni bumi ini. Fenomena aktivitas baru seperti Work from Home, percepatan literasi informasi melalui kegiatan yang terpaksa dilakukan secara daring, kebiasaan kesehatan baru dan pembatasan sosial berskala besar merupakan hal-hal yang perlu diadaptasi dan memungkinkan mengubah budaya dan perilaku lama, selamanya. Di sisi lain, kebencanaan terkait Covid-19 seperti kematian, kemunduran kesehatan dan kesejahteraan merupakan hal-hal yang patut pula diterima dan dimaknai secara tepat.

Analogi proses pemaknaan suatu bencana dapat ditemukan dalam karya klasik psikologi mengenai duka cita yang diteorikan oleh Elizabeth Kubler Ross. Ross mengemukakan bahwa saat individu mendapatkan suatu hal yang mengguncang kehidupannya, akan ada 5 fase respon yang terjadi (Saraswati, 2020), yakni penyangkalan (denial), kemarahan (anger), keinginan melakukan tawar-menawar (bargaining) yang kemudian diikuti dengan fase depresi, (depression) hingga pada akhirnya seseorang mampu dan pada akhirnya sampai pada fase penerimaan (acceptance) atas musibah yang dialaminya.

Salah satu teori Psikologi Populer yang beredar di berbagai media terkait pemaknaan terhadap Covid-19 menjelaskan posisi tiap orang berdasarkan zona pengalaman subjektif. "Siapakah Aku di Era Covid-19" merupakan kata kunci yang menjelaskan posisi seorang individu dalam tiga zona; zona ketakutan, zona belajar dan zona bertumbuh.

Zona ketakutan yaitu zona dengan tingkat kecemasan yang tidak produktif. Zona belajar merupakan zona adaptasi menuju pada suatu upaya pengatasan kecemasan. Zona bertumbuh yaitu bentuk dari penyesuaian diri yang membuat individu menjadi tidak hanya produktif bagi diri sendiri melainkan juga menjadikan dirinya bermanfaat bagi orang-orang yang ada di sekelilingnya. 
Dari dua teori di atas, berikut ini merupakan tabel yang berusaha merangkum posisi, proses dan pemaknaan individu dalam konteks pandemi Covid-19:

\begin{tabular}{|l|l|l|l|}
\hline Fase & Posisi (zona) & Tahapan Grief & Kesadaran \\
\hline $\begin{array}{l}\text { Ada tiga kategori } \\
\text { dan proses yang } \\
\text { dialami dan } \\
\text { dilalui selama } \\
\text { pandemi Covid- } \\
\text { 19 yang } \\
\text { diperkirakan } \\
\text { akan bertahan } \\
\text { hingga tahun } \\
\text { 2022 }\end{array}$ & Takut & $\begin{array}{l}\text { denial dan } \\
\text { anger }\end{array}$ & Mindless \\
\cline { 2 - 4 } & Tumbuh & $\begin{array}{l}\text { menawar dan } \\
\text { depresi }\end{array}$ & Mindfull \\
\cline { 2 - 4 } & $\begin{array}{l}\text { Konsep kebermakna } \\
\text { Covid-19 }\end{array}$ & Meaningful \\
\cline { 2 - 4 } & \multicolumn{3}{|l}{} \\
\hline
\end{tabular}

Pemaknaan sebagai bentuk akhir proses psikologis dalam menghadapi pandemi merupakan zona pertumbuhan pribadi menuju pada produktivitas individu. Individu yang telah berhasil memasuki zona ini telah menjadi pribadi produktif yang nilai kemanfaatan dirinya telah memberikan rahmat bagi lingkungan di sekitarnya. Dalam teori Ross, penerimaan merupakan tahapan akhir dan pada tahap inilah makna telah berhasil masuk dalam diri seorang individu.

\section{KEBERMAKNAAN HIDUP SELAMA PANDEMI}

Pandemi Covid-19 telah mengubah wajah dunia dalam waktu yang sangat cepat, namun dampaknya akan berlangsung selamanya. Pandemi ini mengungkap kerapuhan dan kekosongan makna sekaligus "muka asli" para penduduk bumi yang dalam kehidupan kesehariannya terjebak pada meaningless; kehidupan tanpa makna yang hakiki. 
Pandemi ini memaksa penduduk bumi untuk "berkaca" sambil berjeda dalam kesunyian pembatasan sosial, ketakutan dan kecemasan dalam segala keterbatasan dan penurunan kualitas kehidupan. Tanpa kesadaran diri, tanpa mindfulness, Virus Corona hanyalah bermakna kehancuran dan ketidakberdayaan yang menyisakan luka yang tak terlupakan. Menjadi pribadi dengan kemampuan mindfull, memaksa individu dan masyarakat melepaskan diri dari penjara ketakutan, menuju pada zona belajar, hingga mencapai pertumbuhan pribadi dengan kualitas kesadaran sebagai mahluk bertuhan. Suatu bentuk kepasrahan pada ketentuan Allah SWT dan penerimaan serta pemaknaan bahwa pandemi ini memang harus terjadi.

Alhamdulillah 'ala kulli haal, tidak ada yang sia-sia dari setiap peristiwa yang dikehendakiNya. Adaptasi new normal yang bermakna abnormal harus dilakoni. Manusia dan peradabannya telah belajar dan menjalani ujian dan menghasilkan meaningfulness bagi diri dan sesamanya. Luaran hasil ujian tinggal dijalani dengan baik demi pemaknaan baru kehidupan yang tak seorang manusia pun tahu kapan akan berakhir.

Sitasi

Anwar, F. (2020, 26 Juni). Kapan Corona Berakhir? Ini Prediksi Para Ahli, https://health.detik.com/berita-detikhealth/d5069316/kapan-corona-berakhir-ini-prediksi-para-ahli, diakses pada 1 November 2020,

Arnani, M. (2020, 13 Maret). Kasus Pertama Virus Corona Dilancak Hingga 17 November 2019, https://www.kompas.com/tren/read/2020/03/13/111245765/k asus-pertama-virus-corona-di-china-dilacak-hingga-17november-2019?page=all , diakses pada 1 November 2020 
Cuhendy, E (2020, 7 April). Siapakah Aku di Era Covid-19?, https://www.fkgipsnaspgri.org/2020/04/siapakah-aku-di-eracovid-19.html, diakses pada 1 November 2020

Dundon, E. (2019). From Mindfulness to Meaningfulness. Learning to "feel your time" Diakses dari Psychology Today. Website: https://www.psychologytoday.com/us/blog/thesearch-meaning-after-age-50/201903/mindfulness$\underline{\text { meaningfulness }}$

Himawan, E. (2020, 28 Agustus), 4 Hoax Soal 'Obat Covid-19' yang Sempat Heboh, https://health.detik.com/beritadetikhealth/d-5150880/4-hoax-soal-obat-covid-19-yangsempat-heboh, diakses pada 1 November 2020

Huda, E. S, (2015, 30 Maret), Walisongo (2): Sunan Bonang, Pencipta Tembang Tombo Ati, https://www.dream.co.id/dinar/sunan-bonang-penciptatembang-tombo-ati-150330z.html, diakses pada 1 November 2020

Mindfulness and Mindlessness. Diakses dari Iresearchnet.com.

Psychology Research and Reference. Website:

http://psychology.iresearchnet.com/social-

psychology/control/mindfulness-and-

mindlessness/\#: : :text=Mindlessness\%20is\%20an\%20inactive\%20s tate,on\%20subtle\%20changes\%20in\%20context.

Rahman, A. F., (3 Februari 2020), Daftar 54 Hoax Virus Corona yang Ditemukan Kominfo, https://inet.detik.com/cyberlife/d4883638/daftar-54-hoax-virus-corona-yang-ditemukankominfo , diakses pada 1 November 2020

Saraswati, R., (2020, 5 Maret), Lima Stages of Grief (Tahap

Kesedihan)dan Bagaimana Cara Melaluinya, 
https://www.sehatq.com/artikel/stages-of-grief-tahapkesedihan-dan-bagaimana-cara-melaluinya, diakses pada 1 November 2020

Sawitri, A. A, (2020, 27 Januari), [Fakta atau Hoax] Benarkah Ada Penumpang yang Meninggal karena Virus Corona di Bandara Soekarno-Hatta?, https://cekfakta.tempo.co/fakta/580/fakta-atau-hoaksbenarkah-ada-penumpang-yang-meninggal-karena-viruscorona-di-bandara-soekarno-hatta, diakses pada 1 November 2020

Prasetiyo, W. A. (2020, 30 September), Satgas Sebut 50 Juta Masyarakat tak Percaya Terpapar Covid, https://republika.co.id/berita/qhh2y8467/satgas-sebut-50-jutamasyarakat-tak-percaya-terpapar-covid, diakses pada 1 November 2020

Purnamasari, D. M. (2020, 2 Oktober), Anggota Satgas: Survei BPS, 17 Persen Masyarakat Indonesia tak Percaya Covid-19 https://nasional.kompas.com/read/2020/10/02/16414751/anggot a-satgas-survei-bps-17-persen-masyarakat-indonesia-tak-percayacovid?page=all, diakses pada 1 November 2020

Saputra, A. (2020, 3 Agustus), Muncul Fenomena

Ketidakpercayaan Masyararakat pada Bahaya Virus Corona, https://health.grid.id/read/352273244/muncul-fenomenaketidakpercayaan-masyarakat-pada-bahaya-virus-corona?page=all diakses pada 1 November 2020 


\section{RIWAYAT HIDUP}

Helma Nuraini , S.Psi., M.Pd Helma Nuraini lahir di Malang 44 tahun yang lalu, tinggal di Kota Malang sampai lulus SMA, kuliah di Yogyakarta dan bekerja, menikah dan melanjutkan hidup di Banjarmasin. Dengan berbekal

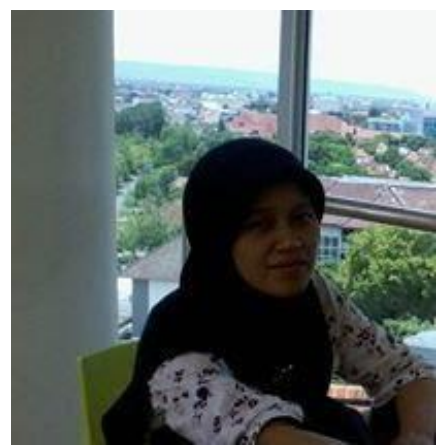

ijazah S1 Psikologi UGM, Helma mendapat pekerjaan sebagai dosen Psikologi di Prodi Bimbingan dan Konseling Pendidikan Islam (BKPI) di Fakultas Tarbiyah dan Keguruan UIN Antasari Banjarmasin. Gelar Magister Pendidikan didapatkan dari Prodi Pendidikan IPS ULM Banjarmasin. Helma Nuraini menikah dengan Sulisno, S,Sn., MA dan dikarunia dua anak laki-laki dan satu anak perempuan dengan nama Aji-Ata-Ayu. Selama pandemi, Helma menghabiskan hampir semua aktivitasnya di rumahnya, di Malkontemon, Sultan Adam Banjarmasin Utara. Untuk dapat berkomunikasi dengan Helma, silakan menghubungi nomor Whatsapp: 08990043973 dan email di hnuraini@gmail.com. Jika pandemi (semoga segera berlalu ) Helma akan dengan senang hati menerima kunjungan Anda di Biro Layanan Bimbingan dan Konseling (BLBK) yang bertempat di Gedung F lantai 2 FTK UIN Antasari Banjarmasin . 